\title{
Capnocytophaga gingivalis: effects of glucose concentration on growth and hydrolytic enzyme production
}

\author{
D. A. Spratt, J. Greenman and A. G. Schaffer \\ Author for correspondence: J. Greenman. Tel: +44 1179763836. Fax: +44 1179763871.
}

Department of Biological Sciences, Faculty of Applied Sciences, The University of the West of England, Frenchay Campus, Coldharbour Lane, Bristol BS1 1QY, UK

\begin{abstract}
In chemostat culture, the microaerophilic, $\mathrm{CO}_{2}$ requiring, gingival-plaqueassociated bacterium Capnocytophaga gingivalis responded to the addition of glucose (1-6 $\mathrm{g} \mathrm{l}^{-1}$ ) by doubling its growth rate and increasing its biomass yield fivefold. The data suggest that the glucose is catabolized by a fully aerobic route. Rather than repressing hydrolytic enzymes which might be associated with pathogenic properties, glucose enhanced the specific activity of aminopeptidase, trypsin-like protease, acid and alkaline phosphatase and $\alpha$ glucosidase in comparison with a control culture grown in a tryptone/thiamin medium. Thus, the supply of glucose could be of importance in maximizing the pathogenic potential of this organism.
\end{abstract}

Keywords: Capnocytophaga ginginalis, continuous culture, glucose, hydrolytic enzymes, extracellular and cell-bound enzymes

\section{INTRODUCTION}

The genus Capnocytophaga was proposed by Leadbetter $e t$ al. (1979), who characterized non-flagellated, gliding, Gram-negative, fusiform bacteria isolated from the oral cavity. Capnocytophaga spp. have been reported to be involved in some forms of periodontal disease (Newman et al., 1976; Slots, 1976) and a variety of non-dental clinical conditions (Forlenza et al., 1980; Winn et al., 1984; Parenti \& Snydman, 1985). The role of Capnocytophaga spp. in periodontal disease is still unclear. These microorganisms have been shown to be a major component of subgingival plaque in juvenile periodontal disease (Newman et al., 1976; Slots, 1976) and in patients with insulin-dependent diabetes mellitus (Mashimo et al., 1983).

Capnocytophaga gingivalis has been shown to produce a range of hydrolytic enzymes (Shibata et al., 1992; Poirier \& Holt, 1983; Nakamura \& Slots, 1982). The saccharolytic glycosidase enzymes include $\alpha$-and $\beta$-glucosidases, $N$-acetylglucosaminidase and $\alpha$ - and $\beta$-galactosidases (Spratt, 1994). Enzymes which contribute to proteolytic activity include trypsin-like protease and aminopeptidase (Shibata et al., 1992; Spratt et al., 1995). Phosphatase activity is also apparent (Poirier \& Holt, 1983). C. gingivalis has been reported to ferment glucose and other sugars (Socransky et al., 1979). The effects of an easily available carbon/energy source, such as glucose, on the control of hydrolytic enzyme production have been investigated for other organisms of medical interest (e.g. Propionibacterium acnes; Holland et al., 1979) but not for Capnocytophaga. Of particular interest is whether glucose exerts differential control on the expression of enzymes involved in saccharolytic or proteolytic patterns of growth. The following study reports on the effects of glucose on the growth of C. gingivalis in continous culture in tryptone/ thiamin medium and on the production of a range of hydrolytic enzymes (trypsin-like protease, aminopeptidase, $\alpha$-glucosidase and acid and alkaline phosphatase) by the organism under these conditions.

\section{METHODS}

Media and chemicals. Tryptone was obtained from Oxoid; Fastidious Anaerobe Agar was obtained from Lab M. All other chemicals were obtained from Sigma.

Organism. Capnocytophaga gingivalis strain A TCC 33624 was used in all experiments. Cultures were maintained on Fastidious Anaerobe Agar supplemented with defibrinated horse blood $(5 \%, v / v)$. Plates were incubated in an anaerobic cabinet (MDH) at $37{ }^{\circ} \mathrm{C}$, in an atmosphere of $\mathrm{N}_{2} / \mathrm{H}_{2} / \mathrm{CO}_{2}(80: 10: 10$, by vol.).

Continuous culture. C. gingivalis was grown in a 11 chemostat vessel with control modules for temperature, $\mathrm{pH}$ and stirrer rate (series 500, LH Engineering). The culture volume was maintained at $750 \mathrm{ml}$. The temperature of the culture was maintained at $37^{\circ} \mathrm{C}\left( \pm 0 \cdot 1{ }^{\circ} \mathrm{C}\right)$ and the $\mathrm{pH}$ at $7 \cdot 0$ ( $\pm 0 \cdot 05$ units) by automatic addition of $2 \mathrm{M} \mathrm{NaOH}$ or $1 \mathrm{M} \mathrm{H}_{2} \mathrm{SO}_{4}$. The impeller speed was 500 r.p.m. ( \pm 10 r.p.m.). The vessel was sparged with $\mathrm{N}_{2}, \mathrm{CO}_{2}$ and air to give an $\mathrm{N}_{2} / \mathrm{O}_{2} / \mathrm{CO}_{2}$ mix of $85: 10: 5$ (by vol.). Basal medium consisted of tryptone $\left(10 \mathrm{~g} \mathrm{l}^{-1}\right)$ and thiamin $\left(0.5 \mathrm{mg} \mathrm{l}^{-1}\right)$. 
Previous experiments have shown that thiamin is an essential Bvitamin for this species (Spratt, 1994). Solutions of sterile glucose were added to the basal medium to give a range of glucose concentrations from 0 to $6 \mathrm{~g} \mathrm{l}^{-1}$.

Maximum specific growth rates. The maximum specific growth rate $\left(\mu_{\max }\right)$ for $C$. gingivalis was determined for each growth condition using a washout method (Tempest, 1970). The dilution rate $(D)$ was set to a point beyond that expected for $\mu_{\max }$ and the concentration of cells (measured by taking $\mathrm{OD}_{540}$ readings with a Jenway 6100 spectrophotometer) was measured against time. A graph of the washout of cells was constructed and $\mu_{\max }$ was calculated from the slope of the linear decline in the natural $\log$ (of optical density) with time, since $\mu_{\max }=D+$ slope of the washout curve.

Biomass estimations. Dry weight was estimated by the method of Holland et al. (1979). Cells were deposited by negative pressure filtration on to pre-dried and weighed membrane filters (Millipore; $25 \mathrm{~mm}, 0.45 \mu \mathrm{m}$ pore size). The membrane plus deposited cells was dried to constant weight under an infrared lamp (domestic, $275 \mathrm{~W}$ at $15 \mathrm{~cm}$ distance) and the dry weight of the cells was calculated by taking the difference between the two weights. Culture $\mathrm{OD}_{540}$ readings were related to cell dry weight by reference to a calibration curve.

Enzyme assays. Samples of $C$. gingivalis cultures were separated into two distinct fractions, cells and supernatant, by centrifugation at $2000 \mathrm{~g}$ for $20 \mathrm{~min}$ at $4{ }^{\circ} \mathrm{C}$. Assays for aminopeptidase (Spratt et al., 1995), trypsin-like protease (Yoshimura et al., 1984), acid phosphatase (pH 5.5) and alkaline phosphatase (pH 9.0) (Bessey et al., 1946) were carried out on both extracellular and cell-bound culture fractions. $\alpha$-Glucosidase activity was assayed in a similar manner to that of phosphatase but using $p$-nitrophenyl $\alpha$-D-glucopyranoside $(0.5 \%, \mathrm{w} / \mathrm{v})$ as the substrate and $0 \cdot 1 \mathrm{M}$ MOPS at $\mathrm{pH} 7 \cdot 5$ as the buffer. The assay stop solution was $0.2 \mathrm{M}$ sodium carbonate.

Steady states. $\mu_{\max }$ values were determined for the control (zero glucose) and for each level of glucose used. From these results, the dilution rates were set to give steady-state growth rates of $0 \cdot 3 \mu_{\max }$ (i.e. $0 \cdot 3 \mu_{\text {rel }}$ ) for each respective condition. Biomass and enzyme activities were determined on samples taken from the chemostat during steady-state growth conditions. Only after a minimum of six culture-volume changes had occurred between particular conditions and readings for enzymes and biomass were constant was steady state considered to have been achieved.

\section{RESULTS AND DISCUSSION}

\section{Effects of glucose on growth and hydrolytic enzymes}

Glucose $\left(1-6 \mathrm{~g} \mathrm{l}^{-1}\right)$ was added to the basal medium as the sole carbohydrate carbon/energy source for continuous culture studies. Biomass yields were compared for cultures grown at steady state at $0.3 \mu_{\text {rel }}$. From the results presented in Table 1, it can be seen that the biomass increased $3 \cdot 5$-fold with the addition of the first increment of glucose $\left(1 \mathrm{~g} \mathrm{l}^{-1}\right)$. The biomass increased to a maximum level at $4 \mathrm{~g} \mathrm{l}^{-1}$, where over a fourfold increase in biomass was measured with respect to the basal medium. The biomass yield then decreased with higher concentrations of glucose.

The $\mu_{\max }$ of the cells with respect to the various glucose concentrations is shown in Table 1 . This shows a $1 \cdot 8$-fold increase in $\mu_{\max }$ following the addition of the first increment of glucose $\left(1 \mathrm{~g} \mathrm{l}^{-1}\right)$ to the basal medium, then a
Table 1. Effect of glucose concentration on the biomass and $\mu_{\max }$ of $C$. gingivalis

The medium used was tryptone/thiamin at a temperature of $37^{\circ} \mathrm{C}$.

\begin{tabular}{|c|c|c|}
\hline $\begin{array}{l}\text { Glucose concn } \\
\qquad\left(\mathrm{g} \mathrm{l}^{-1}\right)\end{array}$ & $\mu_{\max }\left(\mathrm{h}^{-1}\right)$ & $\begin{array}{c}\text { Biomass yield* } \\
\left(\text { g dry wt } 1^{-1}\right)\end{array}$ \\
\hline 0 & $0 \cdot 13$ & $0 \cdot 24(0 \cdot 01)$ \\
\hline 1 & $0 \cdot 24$ & $0.84(0.02)$ \\
\hline 2 & $0 \cdot 27$ & $0.94(0.01)$ \\
\hline 3 & $0 \cdot 30$ & $0.95(0.01)$ \\
\hline 4 & $0 \cdot 31$ & $0.99(0.01)$ \\
\hline 5 & $0 \cdot 32$ & $0.91(0.01)$ \\
\hline 6 & $0 \cdot 28$ & $0.86(0.02)$ \\
\hline
\end{tabular}

* Biomass yields were measured at $0.3 \mu_{\text {rel }}$. Figures in parentheses represent the SEM of nine determinations.

gradual increase in $\mu_{\max }$ with increasing glucose concentration to $5 \mathrm{~g} \mathrm{l}^{-1}$, which gave a $2 \cdot 5$-fold increase in $\mu_{\max }$ with respect to the basal medium. Near maximal growth rates were attained at 3 and 4 g glucose $1^{-1}$. A further increase in glucose concentration (to $6 \mathrm{~g} \mathrm{l}^{-1}$ ) reduced the $\mu_{\max }$ with respect to the $5 \mathrm{~g} \mathrm{l}^{-1}$ level.

The tryptone/thiamin basal medium without glucose could therefore support growth, although both the culture biomass and $\mu_{\max }$ were relatively low. This establishes that peptides and amino acids can be utilized as both carbon/energy and nitrogen sources for the cell but that the efficiency of the system is low.

C. gingivalis is reported to be able to utilize carbohydrates, including glucose, as carbon/energy sources as well as amino acids and peptides (Socransky et al., 1979). The increase of the culture biomass and $\mu_{\max }$ of the cells after the change from zero glucose to 1 g glucose $l^{-1}$ is substantial. This shows that cells can use gluocse as an energy source, thus sparing the peptides and amino acids contained in the tryptone for use as cellular carbon and nitrogen sources. Increments of glucose greater than $1 \mathrm{~g}^{-1}$ caused only small additional increases in biomass. The yield on glucose is approximately $0.6 \mathrm{~g}$ cells ( $\mathrm{g}$ glucose $)^{-1}$, which is similar to that of a prototrophic aerobic or facultatively anaerobic organism (e.g. Escherichia coli) when grown under fully aerobic conditions (Payne, 1970). Taken together, the biomass and $\mu_{\max }$ data suggest that growth is carbon/energy limited in the range of 4-5 g glucose $1^{-1}$ and in carbon/energy excess at glucose levels higher than this.

In general, the enzyme specific activities (Table 2) increased with the first increment of glucose, rose to a peak at intermediate glucose concentrations $\left(2-4 \mathrm{~g} \mathrm{l}^{-1}\right)$ and decreased at higher glucose levels. The aminopeptidase specific activity was very high compared to the other enzymes.

The levels of total enzyme activity for each of the hydrolytic enzymes tested at a glucose concentration of 
Table 2. Effect of glucose concentration on hydrolytic enzyme production, expressed as specific activity [ $\mu$ mol product formed $\left.h^{-1}(m g \text { cell dry } w t)^{-1}\right]$

Figures in parentheses represent the SEM of 12 determinations. CB, cell-bound activity; EC, extracellular activity; Apase, aminopeptidase; TLP, trypsin-like protease; Acid P, acid phosphatase; Alk P, alkaline phosphatase; $\alpha$-Gluc, $\alpha$-glucosidase.

\begin{tabular}{|c|c|c|c|c|c|c|c|c|c|c|}
\hline \multirow{3}{*}{$\begin{array}{c}\text { Glucose } \\
\text { concn }\left(\mathrm{g}^{-1}\right)\end{array}$} & \multicolumn{10}{|c|}{ Specific activity } \\
\hline & \multicolumn{2}{|c|}{ Apase } & \multicolumn{2}{|c|}{ TLP } & \multicolumn{2}{|c|}{ Acid $\mathbf{P}$} & \multicolumn{2}{|c|}{ Alk P } & \multicolumn{2}{|c|}{$\alpha$-Gluc } \\
\hline & CB & EC & $\mathrm{CB}$ & EC & $\mathrm{CB}$ & EC & $\mathrm{CB}$ & EC & CB & EC \\
\hline 0 & $\begin{array}{l}172 \\
(7)\end{array}$ & $\begin{array}{c}23 \\
(0 \cdot 42)\end{array}$ & $\begin{array}{c}0.4 \\
(0.07)\end{array}$ & $0 \cdot 00$ & $\begin{array}{c}11 \\
(0 \cdot 14)\end{array}$ & $\begin{array}{c}4.5 \\
(0.07)\end{array}$ & $\begin{array}{c}6.4 \\
(0.24)\end{array}$ & $\begin{array}{c}1.5 \\
(0 \cdot 15)\end{array}$ & $\begin{array}{r}0.04 \\
(0.01)\end{array}$ & $0 \cdot 00$ \\
\hline 1 & $\begin{array}{l}250 \\
(13)\end{array}$ & $\begin{array}{c}11 \\
(0 \cdot 45)\end{array}$ & $\begin{array}{c}0 \cdot 4 \\
(0 \cdot 10)\end{array}$ & 0.00 & $\begin{array}{r}6.8 \\
(0.68)\end{array}$ & $\begin{array}{c}2.6 \\
(0.06)\end{array}$ & $\begin{array}{c}6.9 \\
(0.2)\end{array}$ & $\begin{array}{c}0.7 \\
(0.08)\end{array}$ & $\begin{array}{c}1.2 \\
(0 \cdot 02)\end{array}$ & $\begin{array}{c}0.05 \\
(0 \cdot 001)\end{array}$ \\
\hline 2 & $\begin{array}{l}320 \\
(19)\end{array}$ & $\begin{array}{c}15 \\
(0 \cdot 70)\end{array}$ & $\begin{array}{c}0.4 \\
(0.02)\end{array}$ & 0.00 & $\begin{array}{r}8.4 \\
(0.30)\end{array}$ & $\begin{array}{c}2.3 \\
(0.03)\end{array}$ & $\begin{array}{l}10 \cdot 0 \\
(0 \cdot 18)\end{array}$ & $\begin{array}{c}0.8 \\
(0.05)\end{array}$ & $\begin{array}{c}1.6 \\
(0.06)\end{array}$ & $\begin{array}{c}0.04 \\
(0.001)\end{array}$ \\
\hline 3 & $\begin{array}{l}255 \\
(14)\end{array}$ & $\begin{array}{c}10 \\
(0 \cdot 36)\end{array}$ & $\begin{array}{c}0.8 \\
(0 \cdot 10)\end{array}$ & $0 \cdot 00$ & $\begin{array}{c}21 \\
(0 \cdot 47)\end{array}$ & $\begin{array}{c}2 \cdot 0 \\
(0 \cdot 07)\end{array}$ & $\begin{array}{l}10 \cdot 1 \\
(0 \cdot 18)\end{array}$ & $\begin{array}{c}1.3 \\
(0.03)\end{array}$ & $\begin{array}{c}1.4 \\
(0 \cdot 10)\end{array}$ & $\begin{array}{c}0.04 \\
(0.001)\end{array}$ \\
\hline 4 & $\begin{array}{l}280 \\
(30)\end{array}$ & $\begin{array}{c}10 \\
(0 \cdot 36)\end{array}$ & $\begin{array}{r}0.14 \\
(0 \cdot 10)\end{array}$ & $0 \cdot 00$ & $\begin{array}{c}44 \\
(0 \cdot 60)\end{array}$ & $\begin{array}{c}3.6 \\
(0.01)\end{array}$ & $\begin{array}{l}12 \cdot 6 \\
(0.20)\end{array}$ & $\begin{array}{c}1 \cdot 0 \\
(0 \cdot 01)\end{array}$ & $\begin{array}{c}1.3 \\
(0 \cdot 04)\end{array}$ & $\begin{array}{c}0.03 \\
(0.001)\end{array}$ \\
\hline 5 & $\begin{array}{l}114 \\
(6)\end{array}$ & $\begin{array}{c}4 \\
(0 \cdot 12)\end{array}$ & $\begin{array}{r}0.13 \\
(0.03)\end{array}$ & $0 \cdot 00$ & $\begin{array}{c}13 \\
(0 \cdot 60)\end{array}$ & $\begin{array}{c}1 \cdot 3 \\
(0 \cdot 03)\end{array}$ & $\begin{array}{c}7 \cdot 6 \\
(0 \cdot 40)\end{array}$ & $\begin{array}{c}0.5 \\
(0.03)\end{array}$ & $\begin{array}{c}0.8 \\
(0 \cdot 01)\end{array}$ & $\begin{array}{c}0.03 \\
(0.001)\end{array}$ \\
\hline 6 & $\begin{array}{l}106 \\
(6)\end{array}$ & $\begin{array}{c}7 \\
(0 \cdot 10)\end{array}$ & $\begin{array}{r}0.05 \\
(0.01)\end{array}$ & 0.00 & $\begin{array}{c}10 \\
(0 \cdot 36)\end{array}$ & $\begin{array}{c}0.6 \\
(0.09)\end{array}$ & $\begin{array}{c}5 \cdot 3 \\
(0 \cdot 1)\end{array}$ & $\begin{array}{c}0.4 \\
(0.02)\end{array}$ & $\begin{array}{c}0.4 \\
(0.01)\end{array}$ & $\begin{array}{c}0 \cdot 001 \\
(0)\end{array}$ \\
\hline
\end{tabular}

$6 \mathrm{~g}^{-1}$ (glucose excess) are significantly lower at the $P<$ 0.001 level (ANOVA), than the levels at 3 g glucose $1^{-1}$, where glucose was considered to be limiting growth. A relative comparison of activity shows that cell-bound activity peaked at 3-4 g glucose $1^{-1}$ for all the hydrolytic enzymes, with the exception of aminopeptidase, which peaked at $2 \mathrm{~g} \mathrm{l}^{-1}$. In contrast, the maximum relative extracellular activity was highest in the basal medium for aminopeptidase and acid and alkaline phosphatase, and highest at $1 \mathrm{~g}$ glucose $\mathrm{l}^{-1}$ for $\alpha$-glucosidase. For trypsinlike protease, the extracellular activity was below the detection limit of the assay. The absence of extracellular trypsin-like protease activity when cells were grown on glucose was also noted by Shibata et al. (1992). For $\alpha-$ glucosidase activity, extracellular activity was undetectable in cultures grown on basal medium (zero glucose). In general, however, for all measured enzymes, the extracellular activity progressively decreased from a maximum at low or no glucose to a minimum at glucose concentrations of 5-6 $\mathrm{g} \mathrm{l}^{-1}$.

The trend shown by both the cell-bound and extracellular enzyme activities may indicate that so-called catabolite repression (Magasanik, 1961) was occurring, whereby a freely available carbon/energy source (glucose in this case) represses the synthesis of enzymes now redundant since they are concerned with acquiring more carbon/ energy. This type of repression also allows conservation of nitrogen (amino acids) needed for more important cellular functions, which under conditions of excess glucose may be the growth-limiting nutrient. The use of glucose as a source of carbon/energy to study the effects of carbon/energy limitation on enzyme production may not reflect the nutritional changes likely to be encountered in vivo, where amino acids, peptides and host proteins are more likely to be the predominant carbon/energy sources. Nevertheless, glucose is present in the oral environment. Sources include that present in gingival crevicular fluid (Parker et al., 1993), the glucose which may be present in food and drink (dietary sources), and glucose which may be liberated from the enzymic hydrolysis of dextran, glycogen and glycoproteins (e.g. mucin) within dental plaque. It is of interest to note that $C$. gingivalis has been associated with the periodontal disease occurring in patients with insulin-dependent diabetes mellitus (Mashimo et al., 1983), a condition where the glucose levels within tissues and in crevicular fluid may be higher than that in subjects without this condition. In patients with insulin-dependent diabetes mellitus, a relationship has been demonstrated between the degree of periodontal breakdown and both elevated blood-glucose levels and levels of glycosylated haemoglobin, which occur as a consequence of high blood glucose (Ainamo et al., 1990; Safkan-Seppälä \& Ainamo, 1992). It is possible that Capnocytophaga glucosidase activity is capable of removing the glucose moieties from glycosylated haemoglobin, thus providing the cells with an additional source of glucose.

This study suggests that $\alpha$-glucosidase is induced or derepressed by glucose. In general, if cells are adapted to growing on peptides or amino acids in the absence of glycosides or carbohydrates, then $\alpha$-glucosidase production would be redundant for the cell and therefore not expressed, thus allowing ATP to be conserved for the cell. Aminopeptidase and trypsin-like protease are repressed by excess glucose, which suggests that their role for the 
cell is (in the absence of glucose) to obtain cell-permeable peptides or amino acids as carbon/energy sources rather than as nitrogen sources. With regard to phosphatase activity, no obvious pattern or trend is observed in response to glucose levels and therefore no special role associated with a saccharolytic or proteolytic pattern of growth can be ascribed to the production of these enzymes.

\section{REFERENCES}

Ainamo, J., Lahtinen, A. \& Uitto, V.-J. (1990). Rapid periodontal destruction in adult humans with poorly controlled diabetes. J Clin Periodontol 17, 22-28.

Bessey, O. A., Lowry, O. H. \& Brock, M. J. (1946). A method for the rapid determination of alkaline phosphatase with five cubic millilitres of serum. J Biol Chem 164, 321-329.

Forlenza, S. W., Newman, M. G., Lipsey, A. I., Siegel, S. E. \& Blachman, U. (1980). Capnocytophaga sepsis: a newly recognized clinical entity in granulocytopenic patients. Lancet 1, 567-568.

Holland, K. T., Greenman, J. \& Cunliffe, W. J. (1979). Growth of propionibacteria on synthetic medium; growth yields and exoenzyme production. J Appl Bacteriol 47, 383-394.

Leadbetter, E. R., Holt, S. C. \& Socransky, S. S. (1979). Capnocytophaga: new genus of Gram-negative gliding bacteria. I. General characteristics, taxonomic considerations and significance. Arch Microbiol 122, 9-16.

Magasanik, B. (1961). Cellular regulatory mechanisms. Cold Spring Harbor Symp Quant Biol 26, 249-256.

Mashimo, P. A., Yamamoto, Y., Slots, J., Park, B. H. \& Genco, R. J. (1983). The periodontal microflora of juvenile diabetics: culture, immunofluorescence and serum antibody studies. $J$ Periodontol 54, 420-430.

Nakamura, M. \& Slots, J. (1982). Aminopeptidase activity of Capnocytophaga. J Periodontal Res 17, 597-603.

Newman, M. G., Socransky, S. S., Savitt, E. D. \& Crawford, A. (1976). Studies in the microbiology of periodontosis. J Periodontol 47, 373-379.

Parenti, D. M. \& Snydman, D. R. (1985). Capnocytophaga species: infections in non-immunocompromised and immunocompromised hosts. J Infect Dis 151, 140-147.
Parker, R. C., Rapley, J. W., Isley, W., Spencer, P. \& Killoy, W. J. (1993). Gingival crevicular blood for the assessment of bloodglucose in diabetic patients. $J$ Periodontol 64, 666-672.

Payne, W. J. (1970). Energy yields and the growth of heterotrophs. Annu Rev Microbiol 24, 17-52.

Poirier, T. P. \& Holt, C. S. (1983). Acid and alkaline phosphatases of Capnocytophaga species. I. Production and cytological localization of enzymes. Can J Microbiol 29, 1350-1360.

Safkan-Seppala, B. \& Ainamo, J. (1992). Periodontal conditions in insulin-dependent diabetes mellitus. J Clin Periodontal 19, 24-29.

Shibata, Y., Fujimura, S. \& Nakamura, T. (1992). Isolation and characterization of enzymes hydrolyzing chymotrypsin synthetic substrate (enzyme 1) and trypsin synthetic substrate (enzyme 2) from the envelope fraction of Capnocytophaga gingivalis. Med Microbiol Immunol 181, 107-115.

Slots, J. (1976). The predominant cultivable organisms in juvenile periodontitis. Scand J Dent Res 84, 1-10.

Socransky, S. S., Holt, S. C., Leadbetter, E. R., Tanner, A. C. R., Savitt, E. \& Hammond, B. F. (1979). Capnocytophaga: new genus of Gram-negative gliding bacteria. III. Physiological characterization. Arch Microbiol 122, 29-33.

Spratt, D. A. (1994). A study of aminopeptidase and otber bydrolytic enzymes produced by Capnocytophaga gingivalis. $\mathrm{PhD}$ thesis, University of the West of England, Bristol, UK.

Spratt, D. A., Greenman, J. \& Schaffer, A. G. (1995). Capnocytophaga gingivalis aminopeptidase: a potential virulence factor. Microbiology 141, 3087-3093.

Tempest, D. W. (1970). The continuous cultivation of microorganisms. I. Theory of the chemostat. Metbods Microbiol 2, 259-276.

Winn, R. E., Chase, W. F., Lauderale, P. W. \& McCleskey, F. K. (1984). Septic arthritis involving Capnocytophaga ocbracea. J Clin Microbiol 19, 583.

Yoshimura, F., Nishikata, M., Suzuki, T., Hoover, C. I. \& Newbrun, E. (1984). Characterisation of a trypsin-like protease from the bacterium Bacteroides gingivalis isolated from human dental plaque. Arch Oral Biol 29, 559-564.

Received 29 December 1995; revised 28 February 1996; accepted 19 March 1996. 